\title{
Indoor air quality assessement and its perception. Case study historic wooden church, Romania
}

\author{
AURELIA ONEȚ ${ }^{1}$, DORINA CAMELIA ILIEȘ ${ }^{2}$, ALEXANDRU ILIEȘ ${ }^{2}$, GRIGORE \\ VASILE HERMAN ${ }^{2}$, LIGIA BURTA ${ }^{3}$, FLORIN MARCU ${ }^{3}$, RALUCA BUHAS ${ }^{4}$, TUDOR \\ CACIORA $^{5}$, ȘTEFAN BAIAS ${ }^{2}$, CRISTIAN ONET, $^{1}$, MARIN ILIEȘ ${ }^{6}$, ANDREEA LINCU ${ }^{5}$
}

\author{
${ }^{1}$ Faculty of Environmental Protection, University of Oradea, $26^{\text {th }}$ Gen. Magheru Street, Oradea, 410048 , \\ Oradea, Romania \\ ${ }^{2}$ Faculty of Geography, Tourism and Sport, University of Oradea, $1^{\text {st }}$ University Street, Oradea, 410087 , \\ Romania \\ ${ }^{3}$ Faculty of Medicine and Pharmacy, 10 Piața 1 Decembrie Street, 410073, Oradea, Romania \\ ${ }^{4}$ Department of Sociology and Social Assistance, University of Oradea, $1^{\text {st }}$ University Street, Oradea, \\ 410 087, Romania \\ ${ }^{5} \mathrm{Ph} . \mathrm{D}$. candidate, Faculty of Geography, Tourism and Sport, University of Oradea, 1st University Street, \\ Oradea, 410 087, Romania \\ ${ }^{6}$ Faculty of Geography, "Babes-Bolyai” University, Sighetu Marmatiei Extension, 6 Avram Iancu \\ Street, Sighetu Marmatiei, 437 500, Romania
}

\begin{abstract}
Inside of the historic wooden church airborne indoor bacteria and fungi were assessed. This was determined through air quality sampling using the „open plate technique”. Petri dish containing Sabouraud medium was used for fungi test, Actinomycetes Isolation Agar and Plate Count Agar for filamentous bacteria and for aerobic mesophilic bacteria, respectively. The bacteria isolated were: Staphylococcus sp., Micrococcus sp., Bacillus sp. and Actinomyces sp. Determination of most common fungi: Aspergillus sp., Penicillium sp.. Alternaria sp., Paecilomyces sp., Cladosporium sp., Stachybotrys sp., Chaetomium sp., Absidia sp., Trichoderma sp., Trichotecium sp., Scopulariopsis sp., Aureobasidium sp. The yeasts belonging to Rhodotorula and Candida species were also isolated. The microorganisms present in indoor air of the wooden curch indicates an intermediate level of contamination according to the guidelines of the sanitary standards. To broaden the data obtained, we conducted a focus group in order to emphasize the subjective assessment of indoor air quality inside the wooden church. Qualitative results are complementary with our air contamination tests results.
\end{abstract}

Keywords Indoor bacteria, fungi, microclimate, heritage wooden church, indoor air quality, preservation, perception.

To cite this article: ONET A, ILIEȘ DC, ILIES A, HERMAN GV, BURTA L, MARCU F, BUHAS R, CACIORA T, BAIAS Ş, ONEȚ C, ILIEȘ M, LINCU A. Indoor air quality assessement and its perception. Case study historic wooden church, Romania. Rom Biotechnol Lett. 2020; 25(3): 1547-1553. DOI: $10.25083 / \mathrm{rb} 1 / 25.3 / 1547.1553$

$\triangle$ *Corresponding author: DORINA CAMELIA ILIES,, Faculty of Geography, Tourism and Sport, University of Oradea, $1^{\text {st }}$ University Street, Oradea, 410087 , Romania

E-mail: iliesdorina@yahoo.com 


\section{Introduction}

The monitoring of the microclimate inside old heritage building (Figure 1), as the wooden church, and also the indoor microbial concentrations of airborne bacteria and fungi are necessary to estimate the health hazard of the visitors, priests and parishioners etc and to create standards for indoor air quality control for better preservation and conservation of the objects inside. Several studies were developed inside this heritage wooden church since 2016 [1, 2, 3, 4]. We continued the research in this sense by monitoring the microclimate and analysing the level of luminosity, and we also aimed at investigating their effect on specific objects from inside the church, as well as the effect of heat distribution on these articles (in time, the paintings can be deteriorated by microbiological contamination, heat, humidity etc.). In order to perform the microbiological investigation we used specific methods; thus, we investigated bacteria and fungi from the air inside the wooden church and analysed them using different exposure time (4 hours), and we also collected and analysed microbiological samples from the surface of various objects inside the wooden church, presented in other studies.

General research upon the microbial degradation of paintings was done [5], Irbe and Andersone, 2008, present the research concerning wood decay because of fungi in

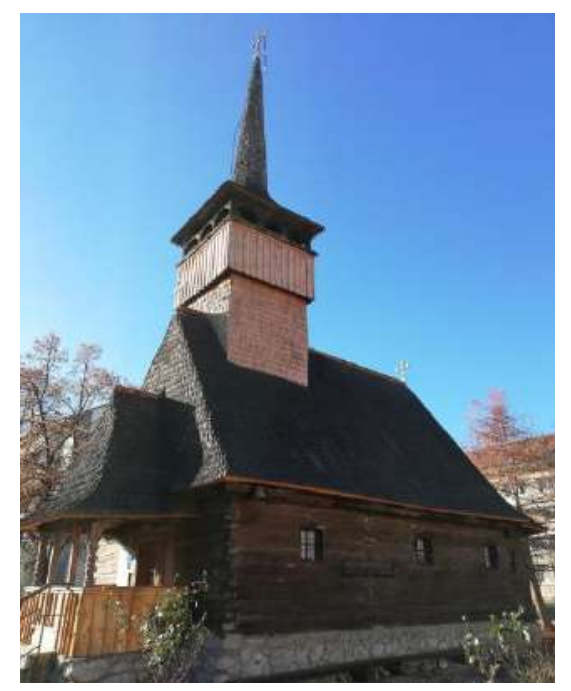

Figure 1. Historic wooden church $\left(\right.$ XVIII $^{\text {th }}$ century), University of Oradea, Romania

\section{Airborne indoor microorganisms isolation}

This study was conducted to determinate the microbial diversity in the historic wooden curch in order to have a preliminary idea of the environmental status. A total of 10 samples were collected in duplicate by open plate method in 5 different points inside the wooden curch (locations: 1. entrance table; 2. up right (the settle plates were placed on beam); 3 . on the floor right; 4 . up left; 5 . in
Latvian heritage buildings [6]. Effects of fungal air pollution on human health hazards was studied by many authors [7, 8, 9, 10, 11]. Microbial-related to risks for artworks and human health in indoor cultural heritage environments (e.g. heritage buildings, museums, churches etc) is a current issue studied by researchers [12, 13, 14, 15]. In Romania we mention the papers [16], concerning the technology for biodegradation of wood from historic monuments, biodegradation issues related to historic monuments from Romania [17]. Issues related to biodeterioration problems of wooden churches wall painting [18], disinfection and consolidation by irradiation of wooden samples case study Romanian churches [19], analyses the macromycetes on the construction wood of historical monuments from Romania [20].

\section{Material and Methods}

\section{Microclimate}

The microclimate inside the historic monument wooden church was monitored in the period March-May 2016 [1, 2, 3, 4], respectively October-December 2018. Was used thermo-hygrometer with data function logger Klimalogg Pro with eight sensors (for the temperature and relative humidity of the air), "Digi-Sense Data Logging Luxmeter" (luminosity), for temperature scan "Thermal Imaging Camera FLIR I7", respectively for $\mathrm{CO}_{2}$ monitoring - NOVA 5000.

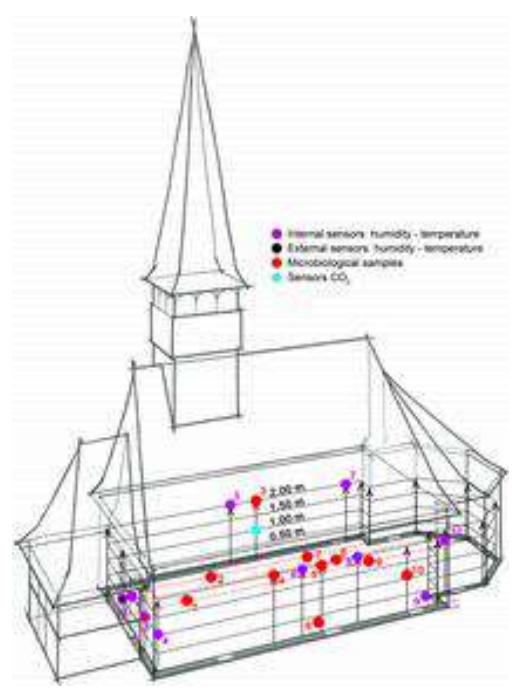

Figure 2. 3D sketch with the distribution of temperature sensors, humidity and $\mathrm{CO}_{2}$, and microbiological samples inside of the wooden church

front of the altar, bottom) (Figure 2). The number of bacteria, Actinomycetes and fungi present in the indoor air of the wooden church was studied by exposing Plate Count Agar (Merck), Actinomycetes Isolation Agar (Merck) and Sabouraud Dextrose Agar (Merck) with addition of chloramphenicol plates for 4 hours. After the exposure and collection, the plates were taken to the Microbiology laboratory and incubated at $37^{\circ} \mathrm{C}$ for 24 hours for isolation 
of bacteria and incubated at $28^{\circ} \mathrm{C}$ for 5-7 days for isolation of fungi and Actinomycetes. The total number of bacteria, yeast and moulds in the air samples collected from the five different locations inside the wooden church was determined [21]. The total number of colony forming unit $\left(\mathrm{CFU} / \mathrm{m}^{3}\right)$ was calculated. After the enumeration of the colony forming units ( $\mathrm{CFU}), \mathrm{CFU} / \mathrm{m}^{3}$ were determined, taking into account the following equation described by Omeliansky [22].

$$
\mathrm{N}=5 \mathrm{a} \times 10^{4}(\mathrm{bt})^{-1},
$$

Where,

$\mathrm{N}=$ microbial $\mathrm{CFU} / \mathrm{m}^{3}$ of indoor air; $\mathrm{a}=$ number of colonies per Petri dish; $b=$ dish surface $\left(\mathrm{cm}^{2}\right)$; $\mathrm{t}=$ exposure time (min).

The bacterial cultures were identified by using staining techniques and macroscopic characteristics. The fungal cultures were identified on the basis of microscopic (using Lactophenol cotton blue staining and macroscopic characteristics [23].

\section{Focus group}

A qualitative research method, was also used to emphasize the subjective assessment of indoor air quality in the wooden church. We consider that a mixed methodological research design can sustain a more complex approach of our research objectives. Focus groups were developed also in other interdisciplinary investigations $[2,26,27,28]$ in order to provide a more in-depth and complex analysis of a specific phenomenon [29].

We developed the focus group inside the wooden church, and we invited six people who are developing some of their activities in this historic wooden church to participate at discussions. We mention that the majority of participants are undertaking their activities inside this church for at least 10 years, therefore they were able to provide us significant information for our research. Also, they develop activities inside the church at least once a week, for about 2-3 hours daily. We mention that all focus group participants have high education level. The intensity of their activity and the length of the time spent inside the wooden church increases during periods of religious holidays, when they have activities at least 2 times/week inside the church. The focus group guide covered aspects related to: subjective perception of indoor air quality, health problems due to indoor air quality, suggestions for improving the air quality inside the wooden church, and their health status. Discussions were moderated by a sociologists who encouraged participants to freely express their opinion about the topics. Eventually, we collected important information about the way indoor air quality in the wooden church is perceived by people.

\section{Results and Discussion}

In terms of monitoring the microclimate inside and outside of the historic wooden church during March-May 2016, respectively October-December 2018, we used thermo-hygrometer with data function logger Klimalogg Pro (eight sensors) for the temperature and relative humidity, Nova 5000 for $\mathrm{CO}_{2}$ monitoring; we performed thermo-scanning by using "Thermal Imaging Camera FLIR I7" and "Digi-Sense Data Logging Luxmeter" for luminosity analysis. The temperature and relative humidity show variations during the measurement time, mainly due to outside weather conditions, church activities and the heating system; so, the highest values were recorded during the service where a large number of parishioners were present (approx. 60 persons). Carbon dioxide $\left(\mathrm{CO}_{2}\right)$ values remain relatively constant over the seven weeks of monitoring, exceeding the dangerous threshold for humans of $1000 \mathrm{ppm}$ (ANSI/ASHRAE Standard, 2003) just to religious services every Sunday, and just for maximum of two hours (Figure 3).

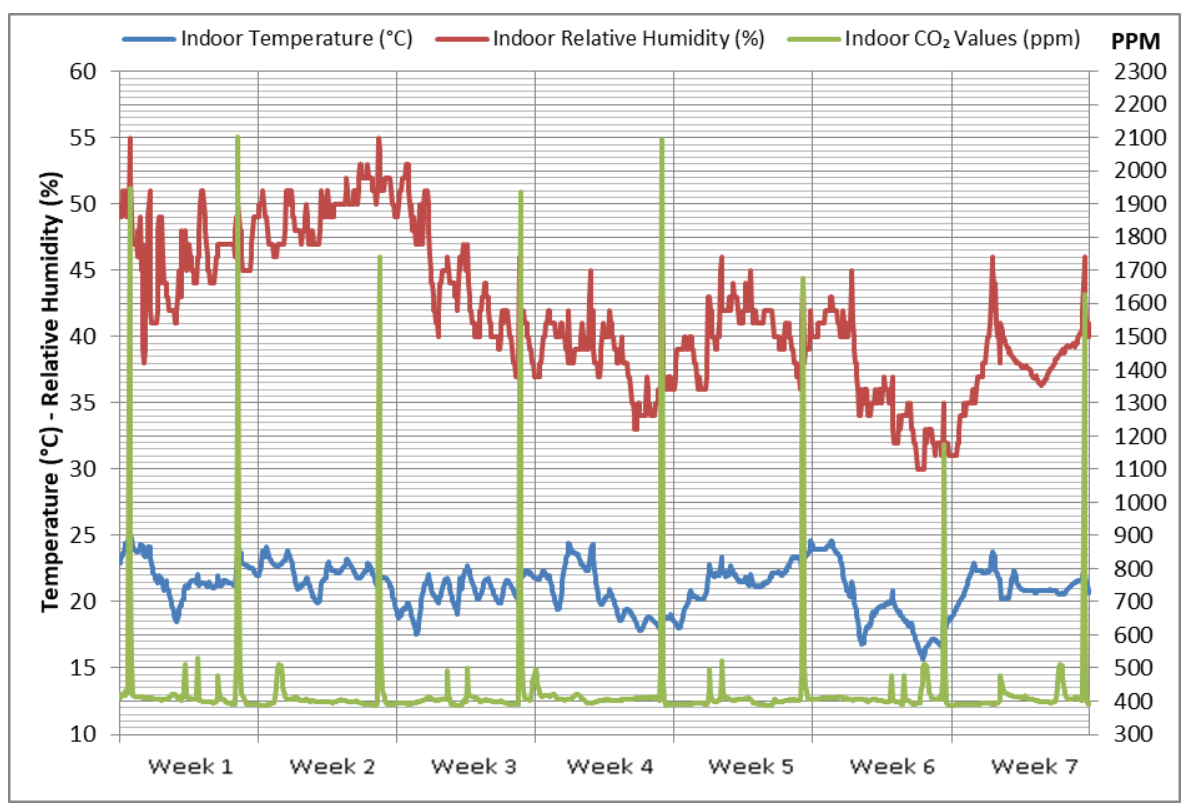

Figure 3. Variation of the air temperature, relative humidity and $\mathrm{CO}_{2}$ values in the heritage wooden church, during monitoring period $(20.10-09.12 .2018)$. 
Microbiological quality assessment of indoor air study is one of the most vital investigations to determine the microbial indoor air pollution [30]. The information on the indoor microbial concentrations of airborne bacteria and fungi is necessary both to estimate the health hazard and to create standards for indoor air quality control [31]. Total number of mesophilic aerobic bacteria, Actinomycetes and filamentous fungi from inside air of the wooden church was determined using Koch sedimentation method. Data collected by sedimentation method allow the drawing of correct conclusions on types of microorganisms present in the air and can give a good approximation of bacterial and fungal concentration [32, 33].

Bacteria were identified by the macroscopic estimation through description of colony and by microscopic estimation using the optical microscope. Diagnosis of filamentous fungi was based on estimation of morphological features of growth on Sabouraud medium [34, 35]. The concentrations of bacterial and fungi aerosols in the indoor environment of the wooden church estimated with the use of the settle plate method, ranged between 95-308 CFU/m ${ }^{3}$ (Table 1).

Table 1. Average number of bacterial and fungal count $\left(\mathrm{CFU} / \mathrm{m}^{3}\right)$ in air samples from the wooden church

\begin{tabular}{|l|c|c|c|}
\hline $\begin{array}{c}\text { Sampling points inside } \\
\text { the wooden church }\end{array}$ & $\begin{array}{c}\text { Heterotrophic aerobic } \\
\text { bacteria } \\
\left(\mathbf{C F U} / \mathbf{m}^{\mathbf{3}}\right)\end{array}$ & $\begin{array}{c}\text { Actinomycetes } \\
\left(\mathbf{C F U} / \mathbf{m}^{\mathbf{3}}\right)\end{array}$ & 226 \\
\hline 1. entrance table & 272 & 308 & 253 \\
\hline 2. up right & 243 & 190 & 167 \\
\hline 3. on the floor right & 230 & 200 & 95 \\
\hline 4. up left & 207 & & 151 \\
\hline
\end{tabular}

In this study, the microbial concentration of indoor air differs from sampling area to area as shown in Table 1. The results show that the average number of highest bacterial concentration of air has been recorded on the entrance table $\left(272 \mathrm{CFU} / \mathrm{m}^{3}\right)$ and average of the lowest bacterial concentration of air has been recorded in the up left area of the church $\left(207 \mathrm{CFU} / \mathrm{m}^{3}\right)$. The highest concentration of Actinomycetes was determined in the up right area of the church $\left(308 \mathrm{CFU} / \mathrm{m}^{3}\right)$ and the lowest concentration in front of the altar, bottom $\left(180 \mathrm{CFU} / \mathrm{m}^{3}\right)$. The average number of highest fungal concentration of air has been recorded again at the entrance table $\left(253 \mathrm{CFU} / \mathrm{m}^{3}\right)$ and the average of lowest fungal concentration of air has been recorded on the floor right $\left(95 \mathrm{CFU} / \mathrm{m}^{3}\right)$. The total of bacterial concentration of air was greater than that of the fungal concentration in all the collection points.

On the basis of these results we can highlight the fact that the air inside the small wooden church is in the range below the high level of contamination according to the sanitary conditions $\left(500-2000 \mathrm{CFU} / \mathrm{m}^{3}\right)$ for non-industrial premises and the microbial contamination level is intermediate (CEC, 1993). According to national standard SC 2009-16219/16.07.2009 the maximum level of mesophylic aerobic bacteria loading for clean air is less than 1500 $\mathrm{CFU} / \mathrm{m}^{3}$ and for infested air is greater than $2500 \mathrm{CFU} / \mathrm{m}^{3}$. The admissible level for air fungi loading is $550 \mathrm{CFU} / \mathrm{m}^{3}$ (SC 2009-16219/16.07.2009). The results presented in the table 1 shows that the bacterial and fungal growth of indoor air in the wooden church did not exceed the limit for clean air quality $\left(1500 \mathrm{CFU} / \mathrm{m}^{3}\right)$ in any of the samples [36].

The fungi identified from aeroflora by the macroscopic and microscopic examination method belong to the genus: Aspergillus sp., Penicillium sp.. Alternaria sp., Paecilomyces sp., Cladosporium sp., Stachybotrys sp., Chaetomium sp., Absidia sp., Trichoderma sp.,
Trichotecium sp., Scopulariopsis sp., Aureobasidium sp. The yeasts belonging to Rhodotorula and Candida species were also isolated. The bacteria isolates included: Staphylococcus sp., Micrococcus sp., Bacillus sp. and filamentous bacteria from genera Actinomyces sp.

In the frame of the similar researches done in 2016 the aeroflora identified by the microscopic examination method [1, 2, 3] belong to the genus: Aspergillus, Penicillium, Stachybotrys, Scopulariopsis, Arthrinium, Mucor, Rhizopus, Absidia, Geotrichum [37]. Bacteria of the type Bacillus and yeasts of the type Rhodotorula have been identified. The bacterial contamination of the air has reached the maximum limit of $100 \mathrm{CFU} / 4 \mathrm{~h}$ meanwhile the fungal contamination has exceeded the contamination level $\mathrm{C}$ which provides $50 \mathrm{CFU} / 4$ hours. It has been highlighted on the basis of that results that the air inside the wooden church had potential risk to human health [3].

In spite of their major source difference, the average fungi density found in the indoor air of the wooden church did appear to follow the same trend with bacterial concentration. This can be explained by the fact that the existed indoor air environmental factors of the wooden church favor fungi and bacteria growth [38]. As indicated in numerous studies, the environmental factors especially dampness enhance microbial growth and multiplication in the indoor atmosphere $[39,40,41]$.

The information on the indoor microbial concentrations of airborne bacteria and fungi is necessary both to estimate the health hazard and to create standards for indoor air quality control. Some fungal genera and bacteria identified indoor, results risky for their preservation and for the human health.

The perception of indoor air quality by using the focus group method. Relevant qualitative data was obtained from the focus group, and we state that these results are 
complementary to air contamination tests conducted inside the wooden church. Data collected was narratively analysed and discussed based on the thematic conceptualisation of focus group questions.

Focus group participants were first asked to provide a general assessment of indoor air quality in the wooden church, by describing how they perceive it at individual level. Subjects were very specific about the indoor air quality, and they outlined various features related to air temperature, humidity, smell etc. The air is perceived by most subjects as being too dry and unventilated, especially early in the morning, before they start their daily activity inside the church. Seasons also influence the temperature from inside, and it is sometimes uncomfortable for people. The temperature is perceived as being too high during summer especially, but also during winter because the heating is too intense: "I feel that the air is too dry.... is not ventilated enough... and also, during summer, the room seems airless because is too hot in here". During summer, in order to lower the air temperature, the air conditioner is turned on. But, participants consider that this practice can lower indoor air quality inside the church, if the air conditioner filters have not been replaced beeing a base for the emergence and spread of bacteria and fungi. Another important aspect related to air quality was underlined by one participant who is spending more time inside the church: especially during seasons with high humidity, a "smell of mould" can be perceived inside: "I can smell mould sometimes here like inside an old house with dampness, and I can feel it up to my lungs ... ... yes, sometimes during spring and autumn".

Some focus group participants suggested that dry air inside the church could be reduced by using humidifiers. But, eventually, this would not be a proper solution for the problem because the church (which is registered as a historical monument) was built mostly of wood and a high degree of humidity could negatively affect it and also the paintings inside the church: "A higher humidity would not be good for all the wood here... for the paintings, can alter the paintings. This church is very old... it was built about 300 years ago. Humidifiers could multiply fungi and bacteria". More vegetation planted around the church is considered by the participants to be beneficial because this can probably slightly lower the temperature inside the church during summer: "More trees, flowers, vegetation around here could probably improve the air quality inside the church".

We must mention that the space inside the wooden church is very small and many people (aprox. 60) are participating to the religious service especially in Sundays and religious holidays, which can also influence indoor air quality. However, even if subjects outlined especially the dryness of the indoor air, they generally assess the air quality as being rather good. Moreover, focus group participants consider that the air quality inside the church is not affecting their health status, which they consider to be rather good, and they did not mention any health related symptoms due to indoor air quality.

\section{Conclusions}

Microbiological quality assessment of indoor air is one of the most vital investigations to determine the microbial indoor air pollution. The information on the indoor microbial concentrations of airborne bacteria and fungi is necessary both to estimate the health hazard and to create standards for indoor air quality control. The most isolates from the inside air of the wooden church are considered as potential candidates involved in the establishment of sick building syndromes and often associated with clinical manifestations like allergy, rhinitis, asthma and conjunctivitis. In this context the attention must be given to control those environmental factors which favor the growth and multiplication of microbes in indoor environment of the wooden church to safeguard the health of visitators and parisioners.

The subjective assessment of indoor air quality by using the focus group method revealed that individuals who are undertaking their activity inside the wooden church perceive a rather good indoor air quality. However, they emphasized some uncomfortable air features such as: dry air, high air temperature during summer, and also the smell of mold especially during seasons with high humidity. But, focus group participants do not relate these air characteristics with possible health problems and they did not develop any negative symptoms during years due to poor air quality inside the wooden church. The researches emphasise that the the wooden church air quality improved after the roof change (2016), did not exceed the limit for clean air quality.

\section{References}

1. D.C. ILIES, A. ONET, F.M. MARCU, O. GACEU, A. TIMAR, Ș. BAIAS, A. ILIEȘ, G.V. HERMAN, M. COSTEA, M. ȚEPELEA, I. JOSAN, J.A. WENDT, Investigations Regarding the Air Quality in the Historic Wooden Church in Oradea City, Romania. Environmental Engineering and Management Journal, 17 (11): 1857-1863, (2018).

2. D.C. ILIEȘ, R. BUHAȘ, A. ILIEȘ, O. GACEU, A. ONET, S. BUHAȘ, D. RAHOTĂ, P. DRAGOȘ, Ș. BAIAS,, F. MARCU, C. ONET, Indoor air quality issues. Case study: The Multipurpose Sports Hall of the University of Oradea. Environmental Engineering and Management Journal), 17 (12): 2812-2818 (2018).

3. D.C. ILIEȘ, A. ONET, J.A. WENDT, M. ILIEȘ, A. TIMAR, A. ILIEŞ, Ș. BAIAS, G.V. HERMAN, Study on Microbial and Fungal Contamination of the Air and Wooden Surfaces Inside of a Historical Church from Romania. Journal of Environmental Biology, 39(6): 980-984 (2018).

4. A. ONET, D.C. ILIEȘ, S. BUHAȘ, D. RAHOTĂ, A. ILIEŞ, Ş. BAIAS, F. MARCU, G.V. HERMAN, Microbial air contamination in indoor environment of University Sports Hall. Journal of Environmental Protection and Ecology, 19(2): 694-703 (2018). 
5. O. CIFERRI, Microbial Degradation of Paintings. Appl Environ Microbiol. 65(3): 879-885 (1999).

6. I. IRBE, I. ANDERSONE, Wood decay fungi in Latvian buildings including cultural monuments, in: J. Gril (Ed.), Proceedings of the International Conference held by COST Action IE0601, Braga, November 5-7, 2008, Firenze University Press, Firenze, 2010, pp. 94-100 (2008).

7. E. ŽUŠKIN, E.N. SCHACHTER, J. MUSTAJBEGOVIĆ, J. PUCARIN-CVETKOVIĆ, J. DOKOJELINIĆ, B. MUČIĆ-PUCIĆ, Indoor air pollution and effects on human health. Periodicum biologorum, 111(1): 37-40 (2009).

8. C.R. ŁUKASZUK, E. KRAJEWSKA-KUŁAK, W. KUŁAK, Effects of fungal air pollution on human health. Prog. Health Sci, 1(2): 156-164 (2011).

9. A. H. KHAN, S.M. KARUPPAYIL, Fungal pollution of indoor environments and its management. Saudi journal of biological sciences, 19(4): 405-426 (2012).

10. D. MÉHEUST, P. LE CANN, G. REBOUX, L. MILLON, J.P. GANGNEUX, Indoor fungal contamination: health risks and measurement methods in hospitals, homes and workplaces. Critical Reviews in Microbiology, 40(3): 248-260 (2014).

11. B. MOUSAVI, M.T. HEDAYATI, N. HEDAYATI, M. ILKIT, S. SYEDMOUSAVI, Aspergillus species in indoor environments and their possible occupational and public health hazards. Current medical mycology, 2(1): 36-42 (2016).

12. R. ORTIZ, M. PÁRRAGA, J. NAVARRETE, I. CARRASCO, E. DE LA VEGA, M. ORTIZ, P. HERRERA, J.A. JURGENS, B.W. HELD, R.A. BLANCHETTE, Investigations of biodeterioration by fungi in historic wooden churches of Chiloé, Chile. Microbial ecology, 67(3): 568-575 (2014).

13. A.R. ESTRADA, E.M. TORRES, M.A.A. VÁZQUEZ, J.L.H. PIÑERO, M.A.G. LUCIO, S.M.S. MARTÍNEZ, Fungal spores in four catholic churches in the metropolitan area of Monterrey, Nuevo León State, Mexico - First study. Annals of Agricultural and Environmental Medicine, 22(2): 221-226 (2015).

14. E. DI CARLO, R. CHISESI, G. BARRESI, S. BARBARO, G. LOMBARDO, V. ROTOLO, M. SEBASTIANELLI, G. TRAVAGLIATO, F. PALLA, Fungi and bacteria in indoor Cultural Heritage environments: microbial-related risks for artworks and human health. Environment and Ecology Research, 4(5): 257264 (2016).

15. H.P. DE CARVALHO, N. MESQUITA, J. TROVÃO, S.F. RODRÍGUEZ, A.C. PINHEIRO, V. GOMES, A. ALCOFORADO, F. GIL, A. PORTUGAL, Fungal contamination of paintings and wooden sculptures inside the storage room of a museum: Are current norms and reference values adequate? Journal of Cultural Heritage, 34, 268-276 (2018).

16. N. AUNER, L. BUCŞA, C. BUCŞA, O. CIOCŞAN, Tehnologia consolidării, restaurării şi protecţia impotriva biodegradării la structurile de lemn ale monumentelor istorice. Editura Alma Mater, Sibiu (2005).

17. L. BUCŞA, C. BUCŞA, Agenţi de biodegradare la monumente istorice din România. Prevenire şi combatere. Editura Alma Mater, Sibiu (2005).

18. C. BUCSA, L., BUCSA, Romanian Wooden Churches Wall Painting Biodeterioration. In Wood science for conservation of cultural heritage-Braga 2008 (pp. 1000-1006). Firenze University Press (2010).

19. M. CUTRUBINIS, K. TRAN, E. BRATU, L. CAILLAT, D. NEGUT, G. Niculescu, Disinfection and consolidation by irradiation of wooden samples from three Romanian churches. In Proc. Int. Conf. on Wood Sci. for Conservation of Cultural Heritage, pp. 5-7 (2008).

20. C. ANA, T. CATALIN, Macromycetes identified on the construction wood of historical monuments from Moldavia and causes of their development. Journal of Plant Development, 17: 63-68 (2010).

21. M.R. AZARI, A. GHAJARI, M.R. MASOUDINEZHAD, N.N. FAGHIH, Airborne microbial contamination of dental units. Tanaffos, 7(2): 54-57 (2008).

22. S.F. HAYLEEYESUS, A.M. Manaye, Microbiological Quality of Indoor Air in University Libraries. Asian Pac J Trop Biomed. 4(Suppl 1): S312-S317 (2014).

23. M. MADIGAN, J. MARTINKO, P. DUNLAP, D. CLARK, Food poisoning and food borne diseases Staphylococcal food poisoning. Brock, Biology of microorganisms $\left(12^{\text {th }}\right.$ Edition). Pearson-Benjamin Cummings, San Francisco, pp.1051-1052 (2009).

24. P. GUIAMET, S. BORREGO, P. LAVIN, I. PERDOMO, S.G. DE SARAVIA, Biofouling and biodeterioration in materials stored at the Historical Archive of the Museum of La Plata, Argentine and at the National Archive of the Republic of Cuba. Colloids and Surfaces B: Biointerfaces, 85(2): 229-234 (2011).

25. F. PINZARI, G. PASQUARIELLO, A. DE MICO, Biodeterioration of paper: A SEM study of fungal spoilage reproduced under controlled conditions. Macromolecular Symposia, 238(1): 57-66 (2006).

26. D.C. ILIEŞ, R. BUHAS, A. ILIEŞ, C. MORAR, G.V. HERMAN, Nymphaea lotus var. Thermalis (Pârâul Peţea nature reserve), brand near extinction of the Băile Felix - Băile 1 Mai (Romania) spa tourism system. Geojournal of Tourism and Geosites, 8 (1): 107-117 (2015).

27. A. ILIES, P.D. HURLEY, D.C. ILIES, S. BAIAS, Tourist Animation-a Chance for Adding Value to Traditional Heritage: Case Studies in the Land of Maramures (Romania). Revista de Etnografie şi Folclor-Journal of Ethnography and Folklore, (1-2), 131-151 (2017).

28. D.C. ILIES, R. BUHAS, M. ILIES, A. ILIES, O. GACEU, A.C. POP, F. MARCU, S.D. BUHAS, M. GOZNER, S. BAIAS, Sport activities and leisure in Nature 2000 protected area - Red Valley, Romania. Journal of Environmental Protection and Ecology, 19(1): 367-372 (2018). 
29. R.A. KRUEGER, M. A. CASEY, Metoda focus grup. Ghid practice pentru cercetarea aplicată, Editura Polirom, Iasi (2005).

30. J. MANDAL, H. BRANDL, Bioaerosols in indoor environment-a review with special reference to residential and occupational locations. The Open Environmental \& Biological Monitoring Journal, 4(1): 83-96 2011.

31. B. RAJASH, L.I. RATTAN, Essential of medical microbiology (4 ${ }^{\text {th }}$ ed.). Jayppe Brothers Medical Publishers, New Delhi, pp. 415-439 (2008).

32. S. BONETTA, S. BONETTA, S. MOSSO, S. SAMPÒ, E. CARRARO, Assessment of microbiological indoor air quality in an Italian office building equipped with an HVAC system. Environmental monitoring and assessment, 161(1-4): 473-483 (2010).

33. A.H.A. AWAD, S.A. FARAG, An indoor biocontaminants air quality. International Journal of Environmental Health Research, 9(4): 313-319 (1999).

34. M. CHEESBROUGH, Medical laboratory manual for tropical countries ( $2^{\text {nd }} e d$.), University Press Cambridge, Cambridge, UK pp. 508-511 (1991).

35. C.J. SCHWAB, D.C. STRAUS, The roles of Penicillium and Aspergillus in sick building syndrome, Adv Appl Microbiol, 55, 215-238 (2004).
36. WORLD HEALTH ORGANIZATION, WHO guidelines for indoor air quality: dampness and mould, World Health Organization, Copenhagen, Denmark (2009).

37. M.C. TIMAR, E. BELDEAN, M. POROJAN, L. GURAU, Field testing and microscopy-important tools for a realistic long-term evaluation of wood improvement treatments. Environmental Engineering \& Management Journal (EEMJ), 8(4): 669-678 (2009).

38. A.P. JONES, Indoor air quality and health. Atmospheric environment, 33(28): 4535-4564 (1999).

39. A. NEVALAINEN, L. MORAWSKA, Eds., Biological Agents in Indoor Environments. Assessment of Health Risks, Work conducted by a WHO Expert Group between 2000-2003, QUT (2009).

40. J.F. MEADOW, A.E. ALTRICHTER, S.W. KEMBEL, J. KLINE, G. MHUIREACH, M. MORIYAMA, Indoor airborne bacterial communities are influenced by ventilation, occupancy, and outdoor air source. Indoor Air, 24(1): 41-48 (2014).

41. M.F. YASSIN, S. ALMOUQATEA, Assessment of airborne bacteria and fungi in an indoor and outdoor environment. Int. J. Environ. Sci. Tech., 7(3): 535-544 (2010). 